Research Article

\title{
Durability Analysis of Sludge Solidified with Soda Residue Subjected to Dry-Wet and Freeze-Thaw Cycles
}

\author{
Jun He $\mathbb{D}$, Lei Zhang, and Chi Zhang \\ School of Civil Engineering, Architecture and Environment, Hubei University of Technology, Wuhan 430068, China \\ Correspondence should be addressed to Jun He; hjunas@163.com
}

Received 15 March 2021; Revised 23 March 2021; Accepted 1 April 2021; Published 17 April 2021

Academic Editor: Lijie Guo

Copyright $\odot 2021$ Jun He et al. This is an open access article distributed under the Creative Commons Attribution License, which permits unrestricted use, distribution, and reproduction in any medium, provided the original work is properly cited.

\begin{abstract}
Soda residue (SR), ground-granulated blast-furnace slag (GGBS), and quicklime (QL) were employed for solidifying sewage sludge, which is a technique for sustainable development by transforming industrial solid waste and sludge into engineering fill material such as backfill material in mine or abandoned caverns. The durability of solidified sludge against dry-wet and freeze-thaw cycles was investigated by unconfined compressive strength (UCS), X-ray diffraction, scanning electron microscopy, and nuclear magnetic resonance tests. The results demonstrated that the SR-GGBS-QL solidified sludge had good dry-wet and freeze-thaw durability. In general, UCS increased at first, but then it decreased to some degree with the increase in dry-wet and freeze-thaw cycles. The cycle number for peak UCS depended on the durability test types and SR content. The UCS values after seven dry-wet cycles or ten freezethaw cycles were higher than the initial values before cycles. The main products detected in SR-GGBS-QL solidified sludge were ettringite, hydroaluminite, and calcium silicate hydrate (C-S-H). In addition, some pollutants such as copper, arsenic, and chromium were stabilized. The weakening effect on the microstructure of the solidified sludge occurred after dry-wet or freeze-thaw cycles. However, the hydration reaction continued with the increase of dry-wet and freeze-thaw cycles, leading to an increase in the amount of hydration products (especially C-S-H) and compact microstructure. These contributed to high UCS values and good dry-wet and freeze-thaw durability. The strength and failure strain of solidified sludge still met the requirement of filling materials after dry-wet or freeze-thaw cycles.
\end{abstract}

\section{Introduction}

As a byproduct of municipal wastewater treatment, sewage sludge has been dramatically produced every year in the world and needs to be treated urgently. Owing to its high moisture content, high content of organic and harmful substances, and poor mechanical performance, sewage sludge was usually solidified or stabilized by curing agent and skeleton materials. Various binders, such as cement, lime, silica fume, phosphogypsum, and some inorganic cementitious materials, have been usually used as curing agents to solidify sludge [1-7]. And skeleton materials used in sludge included bentonite, soil, slag, municipal solid waste, and incineration bottom ash and fly ash [6-13]. More and more solid wastes were investigated on the potential to be used as curing agent or skeleton materials.

Soda residue (SR) is a main waste generated in soda industry, and soda residue pollution has become an important factor that destroys the environment and restricts the development of the salt chemical industry. SR has been used as soil amendment, filling materials in salt caverns, sea reclamation, and filling embankment $[14,15]$. Owing to its components (such as $\mathrm{CaCO}_{3}, \mathrm{CaSO}_{4}$, and $\mathrm{CaCl}_{2}$ ) and granulometric composition (mainly of silt), SR has the potential to be used as a curing agent and skeleton material. For example, SR has been used as one of the main raw materials to prepare a new nonclinker to solidify soil [16]. SR can provide active components to strengthen the skeleton effect when used as a modification agent in muddy soil [17]. When SR is used as solidifier of soft soil, the sulfate and chloride in SR help to form hydration products, such as ettringite and calcium chloroaluminate hydrates, which can improve the strength of the soil [18]. All these studies deepened the understanding of the properties of SR and extended the potential of its applications in solidifying sludge as both curing agent and skeleton material. 
Solidified sludge can be used as the stable and safe filler which meets the engineering requirements and environmental requirements [19]. For example, Lin et al. [9] found that calcium bentonite was a favorable additive to improve the effectiveness of cement to solidify sewage sludge due to its good mechanical properties and advantage to immobilize of pollutants such as alkalinity, organics, copper, and zinc. They concluded that the unconfined compressive strength (UCS) of the treated sludge after 7 days and 28 days could meet the requirement of landfilling and construction material, respectively. Dohnalkova et al. [20] used cement and fly ash to solidify the neutralisation sludge and found that the solidified sludge could be used as a filler material for recultivation and installation of technological units in landfills and a buffer layer or underlayer in the construction of roads or subfloors. One of the possible engineering applications is using solidified sludge as backfill material in mine or abandoned caverns, which can solve the problem of waste disposal and the potential geologic disasters associated with sludge disposal. For example, the shortage of backfill materials is one of the factors that restrict the development of backing mining technology in China; then municipal construction wastes, mine tailings, and some chemical solid wastes including sludge were proposed to be used as filling materials in backfill mining [21]. Therefore, the solidified sludge can be considered as a filling material when there is a large amount of available sludge near the mining area or abandoned caverns. Particularly, adoption of solid waste around the mining area or abandoned caverns as sludge solidifier is a promising approach to restore a safe and green environment.

Dry-wet and freeze-thaw cycles might have effects on the engineering properties of solidified sludge and the stability and safety of sludge pile or backfill. From the previous researches about the durability of solidified sludge (see Table 1), it can be observed that the changes of strength with the dry-wet and freeze-thaw cycles are different due to the difference in sludge type, solidified agent, durability type, and testing conditions. The dry-wet cycle testing conditions, such as drying temperature and time and wetting mode and time, have significant effects on the strength. Under the effect of dry-wet cycles with different testing conditions, the solidified sludge may present monotonous increase $[8,23]$, increase first and then decrease $[12,22]$, or monotonous decrease $[10,13,23]$. The freeze-thaw cycle testing conditions, such as the freezing temperature, the thawing temperature, and the durations, have varying effects on the strength. Some solidified sludge showed a decrease in strength after freeze-thaw cycles $[10,12,25]$, while some presented an increase first and then decrease [22, 24]. Nowadays, little relevant literature is available on the curing and skeleton effects of SR when it is used as a modification agent in sludge and subjected to dry-wet and freeze-thaw cycles.

The aim of this study was to investigate the effects of dry-wet and freeze-thaw cycles on the strength properties of solidified sludge. The sewage sludge was solidified with $\mathrm{SR}$, ground-granulated blast-furnace slag (GGBS), and quicklime (QL). Sludge samples solidified with 3 different
SR contents were cured for 28 days and subjected to different numbers of dry-wet cycle or freeze-thaw cycle. The strength and microstructural and mineralogical characteristics were investigated by unconfined compressive strength tests, X-ray diffraction (XRD), nuclear magnetic resonance (NMR), and scanning electronic microscopy (SEM) technologies. The results from this study are helpful in understanding the durability of SR-GGBS-QL solidified sludge when used as a filling material.

\section{Materials and Methods}

2.1. Materials. The tested sewage sludge was taken from Wuhan Donghu Domestic Sewage Treatment Plant, and its properties are shown in Table 2. The sewage sludge has high contents of water and organic matter and high values of the liquid limit, plastic limit, and plasticity index. The curing agents used are composed of SR, GGBS, and QL. The physical properties and chemical compositions of the GGBS and SR can be found in He et al.'s study [18]. Xue and Chen [11] found that the particles in the size range of 0.075 to $0.85 \mathrm{~mm}$ were conducive to skeleton formation in sludge. About $75 \%$ of the SR particles have a size between 0.075 and $0.85 \mathrm{~mm}$ [18], ensuring that SR has a positive effect on the formation of skeleton in sewage sludge. QL can quickly reduce the moisture content of the sludge and activate GGBS $[11,26]$.The $\mathrm{CaO}$ content in the QL used was more than $98 \%$.

\subsection{Testing Scheme and Procedure}

2.2.1. Testing Scheme. The testing scheme is shown in $\mathrm{Ta}-$ ble 3 . The content is defined as the mass ratio of solidifier to wet sludge. According to the research of He et al. [18], Xue and Chen [11], and the results of preliminary experiments, the GGBS and QL contents were determined and fixed. In order to make the full use of SR, the SR content was the highest compared to those of other additives, and different contents were tested. The $30 \%, 40 \%$, and $50 \%$ SR contents are denoted by S3, S4, and S5, respectively, in the text.

2.2.2. Sample Preparation. The SR and GGBS were dried in an oven at $60^{\circ} \mathrm{C}$ and $105^{\circ} \mathrm{C}$, respectively, for $24 \mathrm{~h}$. Then, the SR and GGBS were ground and passed through a $1 \mathrm{~mm}$ sieve. The solidifiers and the sewage sludge were mixed and stirred thoroughly and then sealed and maturated at $30^{\circ} \mathrm{C}$ for 3 days. Considering the exothermic effect of QL and the need to maintain the consistency of the test conditions, $30^{\circ} \mathrm{C}$ was selected for the maturation of all the samples. After 3 days of maturation, the moisture content of the mixture dropped to a low value (the moisture contents of samples S3, S4, and S5 were $85.8 \%, 82.1 \%$, and $68.2 \%$, respectively). It was conducive to sample preparation and subsequent tests. Before sample preparation, a layer of petroleum jelly was evenly spread on the inner wall of the mold (diameter $3.91 \mathrm{~cm}$ and height $8 \mathrm{~cm}$ ), and then the mixture was put into the mold in 3 layers. Each layer was vibrated and compacted by a compactor to eliminate the air in the sample until the height did not change. When the air bubbles were eliminated, the 
Table 1: Previous literatures on durability of solidified sludge.

\begin{tabular}{|c|c|c|c|c|c|}
\hline Reference & Solidified agents & Soil type & $\begin{array}{l}\text { Durability } \\
\text { type }\end{array}$ & $\begin{array}{l}\text { Cured days and one cycle } \\
\text { condition }\end{array}$ & Results of strength \\
\hline $\mathrm{Hu}[12]$ & $\begin{array}{l}\text { Inorganic cementitious } \\
\text { materials }(20 \%)\end{array}$ & $\begin{array}{l}\text { Sewage } \\
\text { sludge }\end{array}$ & Freeze-thaw & $\begin{array}{c}28 \text { days, }-20^{\circ} \mathrm{C}(24 \mathrm{~h})+20^{\circ} \mathrm{C} \\
(24 \mathrm{~h})\end{array}$ & $\begin{array}{c}\text { Decrease from } 100 \mathrm{kPa} \text { (before } \\
\text { cycle) to } 50 \mathrm{kPa} \text { (6th) then keep } \\
\text { constant } \\
\text { Increase from } 200 \mathrm{kPa} \text { (before } \\
\text { cycle) to } 400 \mathrm{kPa}(1 \mathrm{st}) \text { and } \\
\text { decrease to } 300 \mathrm{kPa}(7 \mathrm{th}) \text { then } \\
\text { destroyed }\end{array}$ \\
\hline $\mathrm{Hu}[12]$ & $\begin{array}{l}\text { Inorganic cementitious } \\
\text { materials }(20 \%)+\text { waste } \\
\text { incineration bottom ash }\end{array}$ & $\begin{array}{l}\text { Sewage } \\
\text { sludge }\end{array}$ & Dry-wet & - & $\begin{array}{c}\text { Increase from } 250 \mathrm{kPa} \text { (before } \\
\text { cycle) to } 600 \mathrm{kPa}(1 \mathrm{st}) \text { and } \\
\text { decrease to } 400 \mathrm{kPa}(4 \mathrm{th}) \text { and } \\
\text { then destroyed }\end{array}$ \\
\hline $\operatorname{Li}[10]$ & $\begin{array}{c}\text { Conditioned with fly } \\
\text { ash }+ \text { lime }+ \text { ferric chloride and } \\
\text { then dewatered }\end{array}$ & $\begin{array}{l}\text { Sewage } \\
\text { sludge }\end{array}$ & Freeze-thaw & $\begin{array}{c}28 \text { days, }-20^{\circ} \mathrm{C} \\
(5 \mathrm{~h})+10 \sim 20^{\circ} \mathrm{C}(3 \mathrm{~h}) \\
28 \text { days, } 60^{\circ} \mathrm{C} \\
(24 \mathrm{~h})+\text { immerse at } 20^{\circ} \mathrm{C} \\
(24 \mathrm{~h})\end{array}$ & $\begin{array}{l}\text { Decrease slightly and strength } \\
\text { loss ratio is about } 15 \% \text { (12th) } \\
\text { Decrease slightly and strength } \\
\text { loss ratio is about } 10 \% \text { (12th) }\end{array}$ \\
\hline $\operatorname{Li}[8]$ & $\begin{array}{c}\text { Bentonite }(10 \sim 20 \%)+\text { cement } \\
(20 \sim 60 \%)\end{array}$ & $\begin{array}{l}\text { Sewage } \\
\text { sludge }\end{array}$ & Dry-wet & $\begin{array}{c}28 \text { days, } 60^{\circ} \mathrm{C} \\
(24 \mathrm{~h})+\text { immerse at } 20^{\circ} \mathrm{C} \\
(24 \mathrm{~h})\end{array}$ & $\begin{array}{l}\text { Increase after } 12 \text { cycles, the } \\
\text { higher the cement content, the } \\
\text { more the difference }\end{array}$ \\
\hline $\begin{array}{l}\text { Yang et al. } \\
{[13]}\end{array}$ & $\begin{array}{c}\text { Soil + quicklime }(20 \%)+\text { curing } \\
\text { agent }(10 \%)\end{array}$ & $\begin{array}{l}\text { Sewage } \\
\text { sludge }\end{array}$ & Dry-wet & $\begin{array}{c}28 \text { days, } 35^{\circ} \mathrm{C}(12 \mathrm{~h})+\text { adsorb } \\
\text { water through porous } \\
\text { stone }+20^{\circ} \mathrm{C}(24 \mathrm{~h})\end{array}$ & $\begin{array}{l}\text { Decrease rapidly ( } \leq 5 \text { cycles) } \\
\text { and then tend to be stable }\end{array}$ \\
\hline \multirow{2}{*}{$\begin{array}{l}\text { Wang et al. } \\
{[22]}\end{array}$} & \multirow{2}{*}{$\mathrm{MgO}(7 \%)+$ fly ash (3\%) } & \multirow{2}{*}{$\begin{array}{l}\text { Dredge } \\
\text { sludge }\end{array}$} & Freeze-thaw & $\begin{array}{c}28 \text { days, }-20^{\circ} \mathrm{C}(24 \mathrm{~h})+20^{\circ} \mathrm{C} \\
(24 \mathrm{~h})\end{array}$ & $\begin{array}{c}\text { Increase from } 900 \mathrm{kPa} \text { (before } \\
\text { cycle) to } 1910 \mathrm{kPa}(16 \mathrm{th}) \text { and } \\
\text { then decrease to } 1400 \mathrm{kPa} \\
\text { (20th) }\end{array}$ \\
\hline & & & Dry-wet & $\begin{array}{c}28 \text { days, } 40^{\circ} \mathrm{C} \\
(24 \mathrm{~h})+\text { immerse at room } \\
\text { temperature }(24 \mathrm{~h})\end{array}$ & $\begin{array}{c}\text { Increase from } 900 \mathrm{kPa} \text { (before } \\
\text { cycle) to } 2320 \mathrm{kPa}(8 \mathrm{th}) \text { and } \\
\text { then decrease to } 1700 \mathrm{kPa} \\
(20 \mathrm{th})\end{array}$ \\
\hline $\begin{array}{l}\text { Liu et al. } \\
{[23]}\end{array}$ & $\begin{array}{c}\text { Cement }(100,150 \text {, and } 200 \mathrm{~kg} / \\
\left.\mathrm{m}^{3}\right)\end{array}$ & $\begin{array}{l}\text { Dredge } \\
\text { sludge }\end{array}$ & Dry-wet & $\begin{array}{l}28 \text { days, } 60^{\circ} \mathrm{C}(8 \mathrm{~h})+\text { vacuum } \\
\text { saturation at } 20^{\circ} \mathrm{C}(16 \mathrm{~h})\end{array}$ & $\begin{array}{l}\text { Decrease after cycle for } 100 \mathrm{~kg} / \\
\mathrm{m}^{3} \text { and increase for } 150 \text { and } \\
200 \mathrm{~kg} / \mathrm{m}^{3}\end{array}$ \\
\hline $\begin{array}{l}\text { Wang et al. } \\
{[24]}\end{array}$ & Cement $(5,10$, and $15 \%)$ & $\begin{array}{l}\text { Lead- } \\
\text { polluted } \\
\text { soil }\end{array}$ & Freeze-thaw & $\begin{array}{c}28 \text { days, }-15^{\circ} \mathrm{C} \\
(3 \mathrm{~h})+20 \pm 1^{\circ} \mathrm{C}(3 \mathrm{~h})\end{array}$ & $\begin{array}{l}\text { Increase when the cycles } \\
\text { increase from } 1 \text { to } 3 \text { and then } \\
\text { decrease }\end{array}$ \\
\hline $\begin{array}{l}\text { Hou et al. } \\
{[25]}\end{array}$ & Sodium silicate (3\%) & Loess & Freeze-thaw & $\begin{array}{c}7 \text { days, }-15^{\circ} \mathrm{C}(12 \mathrm{~h})+15^{\circ} \mathrm{C} \\
(12 \mathrm{~h})\end{array}$ & $\begin{array}{c}\text { Decrease from } 3935 \mathrm{kPa} \\
\text { (before cycle) to } 577 \mathrm{kPa} \text { (20th) }\end{array}$ \\
\hline
\end{tabular}

TABLE 2: Basic characteristics of the sludge.

\begin{tabular}{|c|c|c|c|c|c|c|}
\hline Parameters & \multicolumn{6}{|c|}{ Value } \\
\hline Moisture (\%) & \multicolumn{6}{|l|}{566} \\
\hline $\mathrm{pH}$ & \multicolumn{6}{|l|}{6.45} \\
\hline Organic matter content (\%) & \multicolumn{6}{|l|}{35} \\
\hline Specific surface area $\left(\mathrm{m}^{2} / \mathrm{kg}\right)$ & \multicolumn{6}{|l|}{203.0} \\
\hline Atterberg limits & \multicolumn{2}{|c|}{$\begin{array}{c}\text { Liquid limit }(\%) \\
380.31\end{array}$} & \multicolumn{2}{|c|}{$\begin{array}{c}\text { Plastic limit }(\%) \\
62.92\end{array}$} & \multicolumn{2}{|c|}{$\begin{array}{c}\text { Plasticity index } \\
317.39\end{array}$} \\
\hline Main chemical compositions (\%) & $\begin{array}{l}\mathrm{SiO}_{2} \\
45.1\end{array}$ & $\begin{array}{c}\mathrm{P}_{2} \mathrm{O}_{5} \\
16.4\end{array}$ & $\begin{array}{c}\mathrm{Al}_{2} \mathrm{O}_{3} \\
12.9\end{array}$ & $\begin{array}{c}\mathrm{Fe}_{2} \mathrm{O}_{3} \\
6.7\end{array}$ & $\begin{array}{c}\mathrm{CaO} \\
5.6\end{array}$ & \\
\hline Heavy metals (mg/kg dry sludge) & $\begin{array}{c}\mathrm{Cu} \\
0.326\end{array}$ & $\begin{array}{c}\mathrm{Zn} \\
22.190\end{array}$ & $\begin{array}{c}\mathrm{Pb} \\
3.778\end{array}$ & $\begin{array}{c}\mathrm{Cd} \\
0.160\end{array}$ & $\begin{array}{c}\mathrm{Cr} \\
0.974\end{array}$ & $\begin{array}{c}\mathrm{Ni} \\
0.566\end{array}$ \\
\hline
\end{tabular}

vibration or compaction would not affect the density of the mixture sample under high water content [26]. Then, the sample was demolded and cured in a curing box with a temperature of $20 \pm 1^{\circ} \mathrm{C}$ and a humidity of $>90 \%$ for 28 days.
2.2.3. Dry-Wet Cycles and Freeze-Thaw Cycles. Since there is no standard method for dry-wet cycle test at present, the dry-wet cycle was referred to the test method proposed by the Japanese Highway Association and Kamei et al. [27, 28]. 
TABLE 3: Summary of testing scheme.

\begin{tabular}{|c|c|c|c|c|c|c|}
\hline \multicolumn{2}{|c|}{ Testing program } & SR content $(\%)$ & GGBS content (\%) & QL content (\%) & Curing time (days) & Number of cycles \\
\hline \multirow{4}{*}{ Dry-wet cycles } & UCS & $30,40,50$ & 20 & 12 & 28 & $0,1,2,3,4,5,6,7$ \\
\hline & XRD & 50 & & & & $0,1,6,7$ \\
\hline & SEM & 50 & & & & $0,3,6$ \\
\hline & NMR & 50 & & & & $0,3,6$ \\
\hline \multirow{4}{*}{ Freeze-thaw cycles } & UCS & $30,40,50$ & 20 & 12 & 28 & $0,1,3,6,10$ \\
\hline & $\mathrm{XRD}$ & 50 & & & & $0,1,10$ \\
\hline & SEM & 50 & & & & $0,1,6$ \\
\hline & NMR & 50 & & & & $0,1,10$ \\
\hline
\end{tabular}

Before the dry-wet cycle, the mass and volume of the samples after being cured for 28 days were measured. The sample was dried at $20 \pm 1{ }^{\circ} \mathrm{C}$ for $24 \mathrm{~h}$ and then put into a beaker. Water was added to the beaker until the sample was submerged. The sample was immersed in water for another $24 \mathrm{~h}$. This process was one dry-wet cycle. The strength tends to be stable after 7 cycles [23], so the number of dry-wet cycle was selected as $0 \sim 7$. In order to prevent moisture from evaporating during the freeze-thaw cycles, the sample was wrapped with plastic wrap and put in the freezer. The freezethaw cycles were carried out with reference to the test method proposed by the American Society for Testing and Materials [29], Wang et al. [24], and Hou et al. [25]. The process of each freeze-thaw cycle was designed as follows: $-15^{\circ} \mathrm{C}$ for $24 \mathrm{~h}$ and $20^{\circ} \mathrm{C}$ for another $24 \mathrm{~h} .1,3,6$, and 10 freeze-thaw cycles were implemented on the samples. Then, the mass, UCS, and moisture content of the samples were measured after the dry-wet or freeze-thaw cycles.

2.2.4. Testing Methods. The UCS test was conducted based on the Standard for Geotechnical Testing Method (GB/T 50123-2019) [30]. The vertical load was applied at a constant displacement rate of $1.18 \mathrm{~mm} / \mathrm{min}$ until the specimen failed. In order to achieve reliable results, two replicate specimens were prepared for each test, and the average value and margin of error of the results were reported. The specimens after UCS tests were used for XRD and SEM analyses. In XRD analysis (Bruker AXS, Madison, WI, USA), the specimen was firstly dried at $50^{\circ} \mathrm{C}$ and milled into fine particles and then scanned with a rate of $2^{\circ} / \mathrm{min}$ from $10^{\circ}$ to $75^{\circ}$. The specimen was cut into blocks of about $1 \mathrm{~cm}^{3}$ and dried at $50^{\circ} \mathrm{C}$. A block after drying was taken for SEM analysis (SU8010, Hitachi Ltd., Tokyo, Japan). Although drying at $50^{\circ} \mathrm{C}$ might lead to shrinkage and change the microstructure to some degree, the mineral compositions can be revealed in SEM images. Another batch of specimens with SR content of 50\% (see Table 3) was prepared and subjected to dry-wet or freeze-thaw cycles. Then, a cylinder specimen was sampled using a small syringe and put into the NMR analysis (MicroM12025VR, Suzhou Niumag Analytical Instrument Corporation, Suzhou, China). The $T_{2}$ distribution of the inversion curve generated by NMR analysis can be used to estimate the pore size distribution. The soil pores are assumed as ideal spheres; then, the diameter of the pore is proportional to $T_{2}$ [31].

\section{Results and Discussion}

\subsection{Dry-Wet Cycles}

3.1.1. Unconfined Compressive Strength. The stress-strain curves and UCS of solidified sludge subjected to dry-wet cycles are shown in Figure 1. The values of failure strain for all samples were in the range of $1 \%$ and $2 \%$, with the brittle failure characteristics. In general, sample S5 had higher UCS compared with samples S4 and S3, and the difference between S4 and S3 was negligible. This indicated that sufficient amount of SR was needed to play the curing and skeleton roles in solidified sludge. The slight decrease in UCS after the 1st drying-wetting cycle could be observed for all samples. The UCS increased until the 5th or 6th cycle and then decreased slightly. After seven dry-wet cycles, the UCS for samples S5, S4, and S3 were 557.30, 320.77, and $346.16 \mathrm{kPa}$, respectively, which were $1.36,1.16$, and 1.45 times of those before dry-wet cycle.

Zhang et al. [32] proposed that the requirements of filling engineering were the UCS higher than $200 \mathrm{kPa}$ and the failure strain less than $2.8 \%$ after being cured for 28 days. The minimum common standard for compressive strength in the Czech Republic is $400 \mathrm{kPa}$ for the additive granulate for embankments and backfills for other constructions [20]. The minimum UCS required in the USA is $350 \mathrm{kPa}$ after 28 days of curing for waste deposited on the landfill as a structural or substrate material [33]. Generally, all the samples after drywet cycles had the UCS greater than $200 \mathrm{kPa}$ and failure strain less than $2.8 \%$ [31], which meet the requirements of filling engineering. The limit UCS of $400 \mathrm{kPa}$ [20] can be met for sample S5 even after seven dry-wet cycles and the UCS for samples S4 and S3 close to $350 \mathrm{kPa}$ [33].

3.1.2. Mass Loss Rate. Variations in the mass loss rate of solidified sludge with dry-wet cycles are shown in Figure 2. The mass loss rate $\left(\Delta_{m}\right)$ is defined as

$$
\Delta_{m}=\frac{m_{0}-m_{n}}{m_{0}} \times 100 \%,
$$

where $m_{0}$ and $m_{n}$ are the mass of the sample before dry-wet cycle and after the $n$th cycle, respectively. It can be seen that $\Delta_{m}$ of solidified sludge increases firstly and then becomes stable after three dry-wet cycles. The $\Delta_{m}$ for sample S4 was lower than that of samples S5 and S3. More hydration products and higher filling and cementing effects might contribute to the lower $\Delta_{m}$ for sample S4 than sample S3. The 

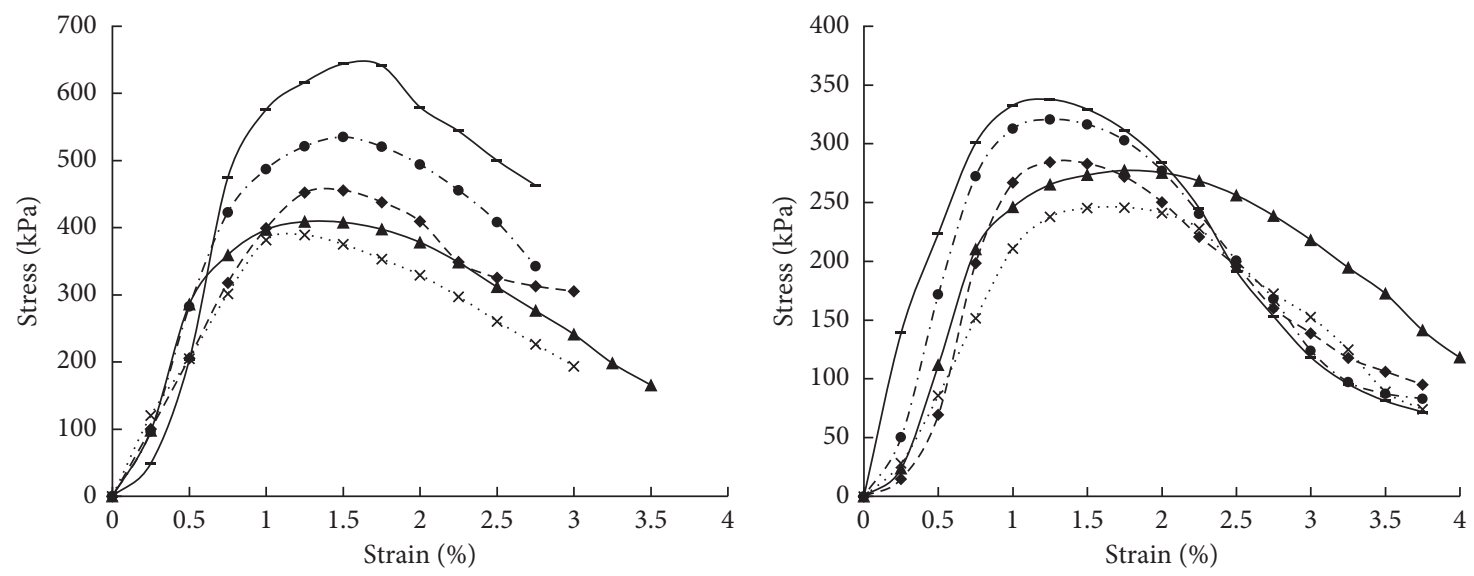

Dry-wet cycles

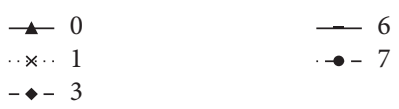

(a)

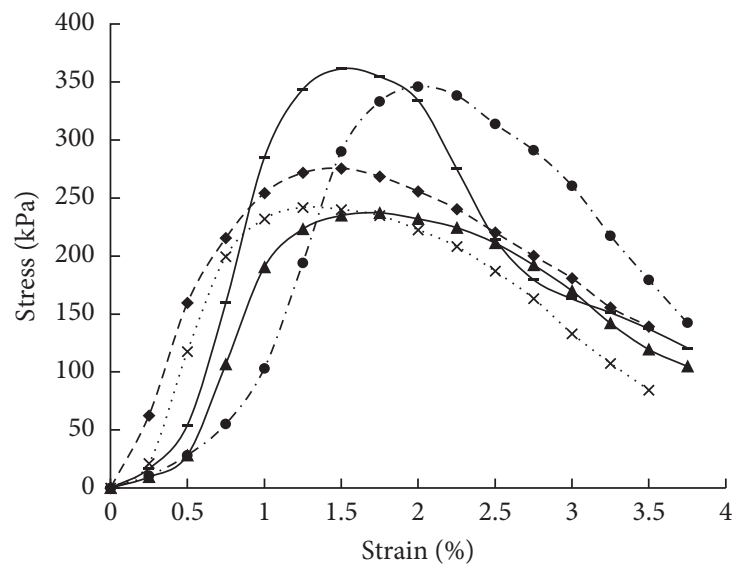

Dry-wet cycles

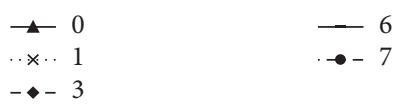

(c)
Dry-wet cycles

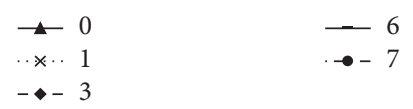

(b)

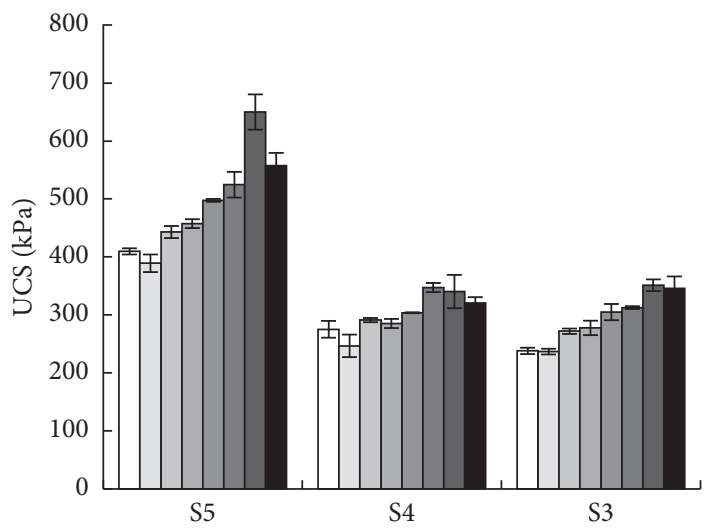

Dry-wet cycles

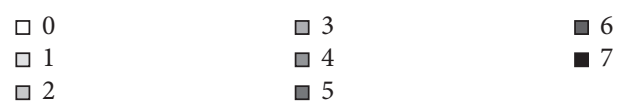

(d)

FIgURE 1: The stress-strain curves for samples (a) S5; (b) S4; (c) S3; and (d) UCS under dry-wet cycles.

dissolution of some substances in sample $\mathrm{S} 5$ such as ardealite (as will be shown in Figure 3(b)) might contribute to the greater than sample S4. All the values of $\Delta_{m}$ were less than $4 \%$, similar to the results reported by $\mathrm{Li}[10]$.

3.1.3. Moisture Content. Variations in moisture content of the solidified sludge with dry-wet cycles are shown in Figure 4. The initial moisture content of the samples before dry-wet cycle decreased with the increase in SR content. The sample before the cycle was unsaturated, so the initial moisture content was lower than that after the 1st dry-wet cycle. The increase in moisture content and sharp increase in $\Delta_{m}$ for the 1st dry-wet cycle might partly contribute to the slight decrease in UCS (Figure 1(d)). Generally, the moisture content decreased as the dry-wet cycles increased from one to seven.

\subsection{Freeze-Thaw Cycles}

3.2.1. Unconfined Compressive Strength. The stress-strain and UCS of solidified sludge subjected to freeze-thaw cycles are shown in Figure 5. Similar to those subjected to dry-wet cycles, the stress-strain curves show obvious brittle failure characteristics, with failure strains between $1.3 \%$ and $2 \%$. The UCS values of sample S5 after freeze-thaw cycles were higher than samples S4 and S3. When the sample subjected to one freeze-thaw cycle, the UCS increased significantly. The UCS for samples S5 and S4 decreased for the further cycles, while the UCS for sample S3 decreased after the 6th cycle. After ten freeze-thaw cycles, the UCS for samples S5, S4, and S3 were $454.26,345.52$, and $365.80 \mathrm{kPa}$, respectively, which were $1.11,1.25$, and 1.54 times of those before cycles. Similar to the results of dry-wet cycles, the UCS of sample S5 exceeded the limit of $400 \mathrm{kPa}$ [20], and the UCS 


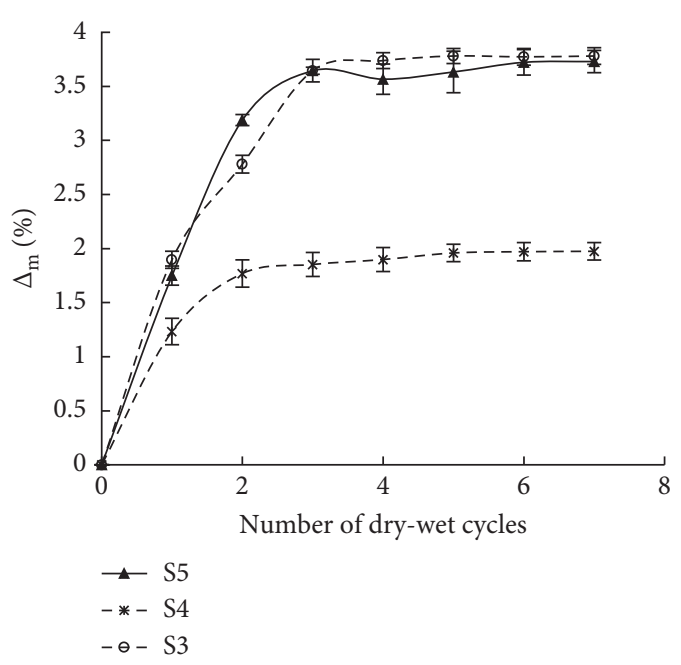

Figure 2: Variations in mass loss rate with dry-wet cycles.

of samples S4 and S3 was greater than or close to $350 \mathrm{kPa}$ [33]. The UCS and failure strain of all the samples after ten freeze-thaw cycles met the requirements of filling engineering [32].

3.2.2. Moisture Content. Variations of moisture content of the solidified sludge with freeze-thaw cycles are shown in Figure 6. The lower moisture content was observed on the samples after one freeze-thaw cycle. Different from the samples subjected to dry-wet cycles, the samples in freeze-thaw cycles were sealed, and no water exchange with the environment occurs. The drop of moisture content for the 1st freeze-thaw cycle might be attributed to the variations of composition under the effect of temperature change, such as more assumption of portlandite and formation of calcium silicate hydrate (as will be shown in Figures 3(c) and 7(g) and 7(h)). After 10 freeze-thaw cycles, the moisture content of samples S3, S4, and S5 was 79.12\%, 70.43\%, and 67.24\%, respectively. The moisture content reduction is $2.64 \%, 4.88 \%$, and $1.01 \%$ compared with the samples before freeze-thaw cycles.

3.3. Microstructural Characteristics. The XRD patterns and SEM images for the solidified sludge are shown in Figures 3 and 7 . The results from Figure 3(a) demonstrated that the amount of portlandite $\left(\mathrm{Ca}(\mathrm{OH})_{2}\right)$ decreased with the increase in SR content. Portlandite originated mainly from QL, and the QL content was same for samples S5, S4, and S3. Therefore, the low content of portlandite in sample S5 indicated that more $\mathrm{QL}$ had participated in hydration reactions. The ettringite $\left(\mathrm{Ca}_{5} \mathrm{Al}_{2}\left(\mathrm{SO}_{4}\right)_{3}(\mathrm{OH})_{12} \cdot 26 \mathrm{H}_{2} \mathrm{O}\right)$ and bentorite $\left(\mathrm{Ca}_{6} \mathrm{Cr}_{2}\left(\mathrm{SO}_{4}\right)_{3}(\mathrm{OH})_{12} \cdot 26 \mathrm{H}_{2} \mathrm{O}\right)$ formed in all samples, which were of lower content for sample S3. Ettringite formed from sulfate in SR and portlandite, which were needle-like and could be observed clearly in Figures 7(a) and 7(b). The formation of ettringite can transform free water into bound water, connect the particles, and fill the pores. These effects helped to improve the short-term and long-term strength of solidified sludge [28]. Bentorite is a $\mathrm{Cr}^{3+}$ analogue of ettringite, indicating that the interaction between solidifier and pollutions in the sludge occurred. Portlandite reacted with chloride in SR to form hydrocalumite $\left(\mathrm{Ca}_{2} \mathrm{Al}(\mathrm{OH})_{6} \mathrm{Cl} \cdot 2 \mathrm{H}_{2} \mathrm{O}\right)$ which was a layered bimetallic hydroxide and could adsorb heavy metals in the sludge [34]. In addition, geminate $\left(\mathrm{Cu}^{2+} 2 \mathrm{As}^{2+} 5 \mathrm{O}_{7} \cdot 3 \mathrm{H}_{2} \mathrm{O}\right)$ or stichtite $\left(\mathrm{Mg}_{6} \mathrm{Cr}_{2} \mathrm{CO}_{3}(\mathrm{OH})_{16} \cdot 4 \mathrm{H}_{2} \mathrm{O}\right)$ could be detected at $2 \theta$ of $11.1^{\circ}$, indicating that some pollutants, such as copper, arsenic, and chromium in the sludge, might have been stabilized. Calcium silicate hydrate (C-S-H) was also detected in all samples, although some peaks might be overlapped by other phases [10]. Some C-S-H could also be observed in Figure $7(\mathrm{~b})$. Ardealite $\left(\mathrm{Ca}\left(\mathrm{SO}_{4}\right)\left(\mathrm{PO}_{3}(\mathrm{OH})\right)\right.$. $4 \mathrm{H}_{2} \mathrm{O}$ ) can be detected in samples S5 and S4, which easily formed in sulfate environment when SR content was high [35].

Figures 3(b) and 7(c) 7(f) show the XRD patterns and SEM images of sample S5 subjected to different number of dry-wet cycles. With the increase in dry-wet cycles, the content of portlandite decreased, while the ettringite peaks showed an increase trend. This indicated that the hydration reaction continued with the increase in dry-wet cycles. The ardealite peak disappeared after the 1st dry-wet cycle. Ardealite is a monoclinic crystal system, and the sulfate in ardealite can be replaced [35]. Besides needle-like ettringite, more C-S-H gels could be observed in samples after dry-wet cycles (Figures 7(c) and 7(d)). After six dry-wet cycles, some $\mathrm{C}-\mathrm{S}-\mathrm{H}$ gels on the surfaces of portlandite crystal and more compact microstructure could be observed, which contributed to the higher UCS than that before dry-wet cycle.

Figures 3(c) and $7(\mathrm{~g}) \sim 7(\mathrm{j})$ show the XRD patterns and SEM images of sample S5 subjected to different freeze-thaw cycles. As shown in Figure 3(c), the XRD pattern for sample after the 1st freeze-thaw cycle was different from that before cycle. Ardealite after the 1st freeze-thaw cycle was weaker, similar to that after dry-wet cycles. Halite $(\mathrm{NaCl})$ could not be observed before freeze-thaw cycle, while the peaks of halite were strongly highlighted after freeze-thaw cycles. Meanwhile, the peaks of hydrocalumite were much lower, indicating that the chloride in hydrocalumite transformed into halite. The transformation might provide phases such as calcium and aluminum to form other hydration products. The peaks of ettringite, bentorite, and portlandite were also lower after the 1st freeze-thaw cycle. Large-dimension ettringite occurred in the sample after the 1st freeze-thaw cycle (Figure $7(\mathrm{~h})$ ) might have an adverse effect on the microstructure due to the uneven expansion. However, the higher peaks of C-S-H in Figure 3(c) and more C-S-H gels in Figure $7(\mathrm{~h})$ contributed to the increase in UCS after the 1st freeze-thaw cycle. Compared with the 1st freeze-thaw cycle, halite peaks decreased slightly while portlandite and hydrocalumite peaks increased for the sample after ten freeze-thaw cycles. Many C-S-H gels and compact microstructure was observed in samples after 10 freeze-thaw cycles (Figures $7(\mathrm{i})$ and $7(\mathrm{j})$ ).

In addition, geminite and stichtite peaks still existed after dry-wet or freeze-thaw cycles, indicating that the pollutants were still stabilized in the solidified sludge. SR, GGBS, and 

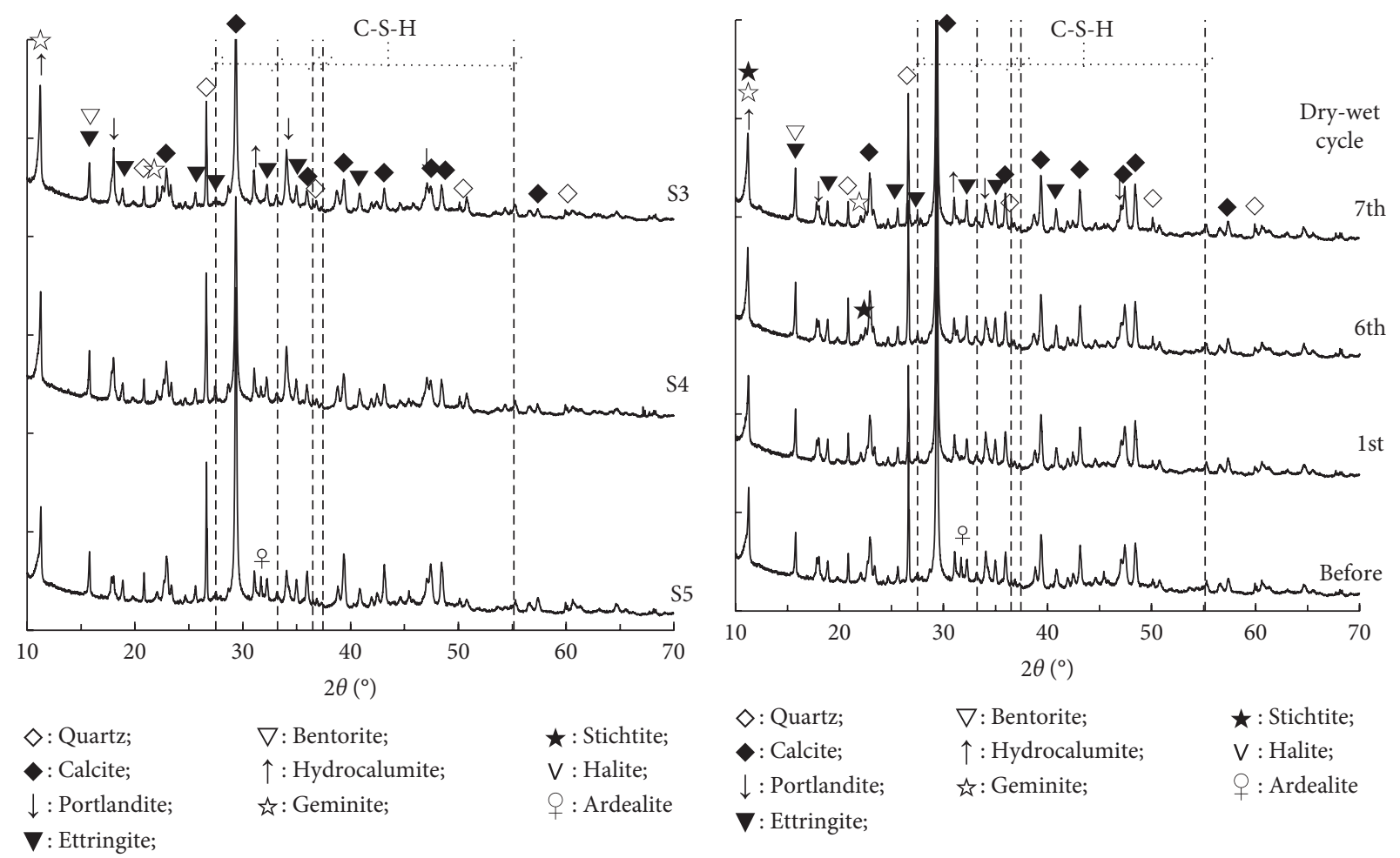

$\diamond:$ Quartz;

$\checkmark$ : Calcite;

$\nabla:$ Bentorite;

$\star$ : Stichtite;

$\downarrow$ : Portlandite;

$\uparrow:$ Hydrocalumite;

$\checkmark$ : Halite;

$\boldsymbol{\nabla}$ : Ettringite;

伩: Geminite;

우:Ardealite

(a)

(b)

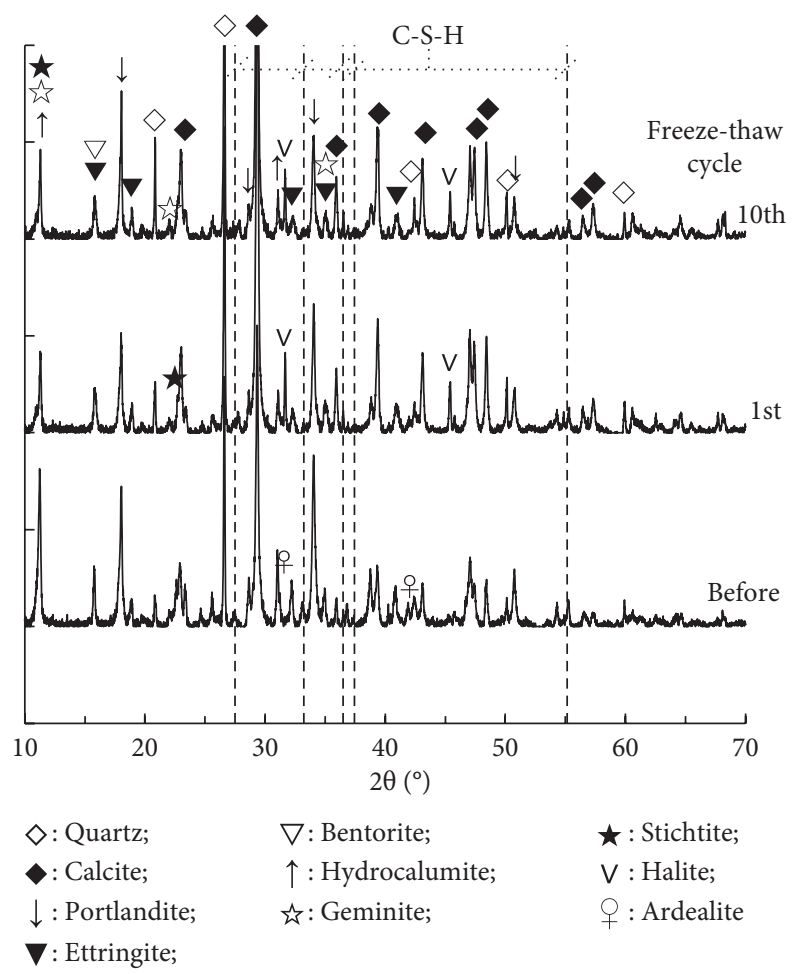

(c)

FIGURE 3: XRD diagram for (a) samples S5, S4, and S3 before cycle; and sample S5 under the effects of (b) dry-wet cycles and (c) freeze-thaw cycles. 


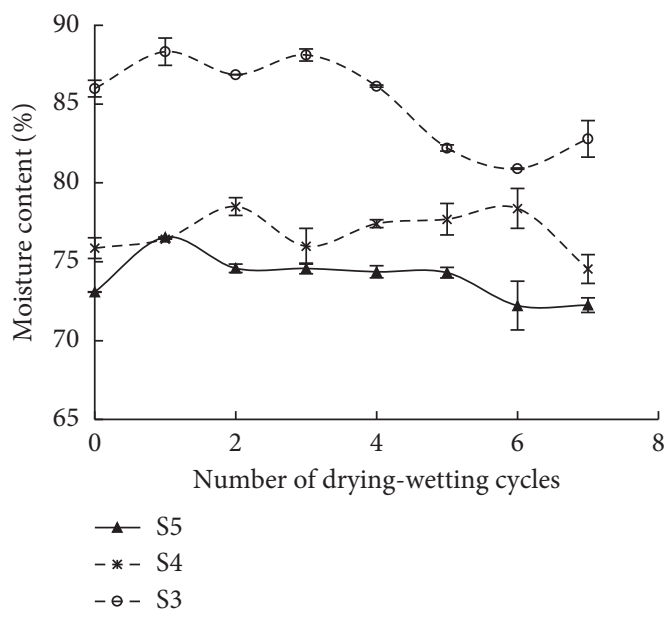

Figure 4: Variations in moisture content with dry-wet cycles.
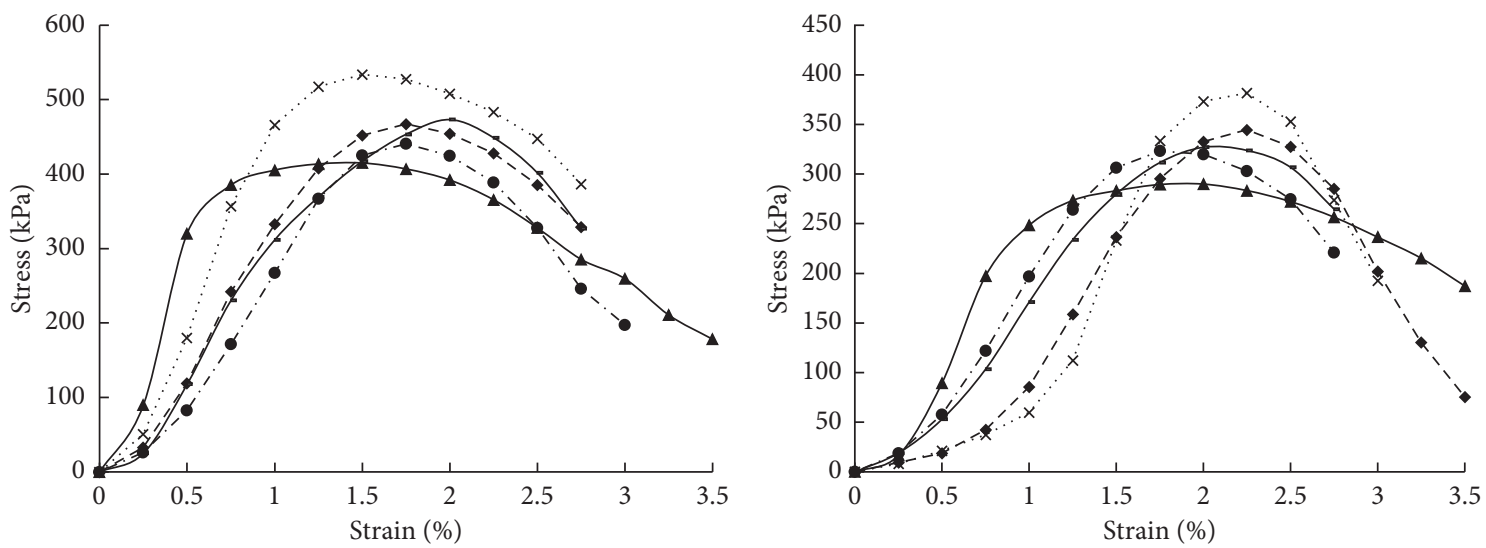

Freeze-thaw cycles

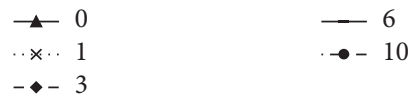

Freeze-thaw cycles

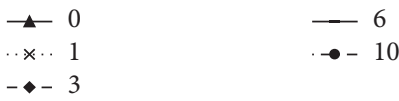

(a)

(b)
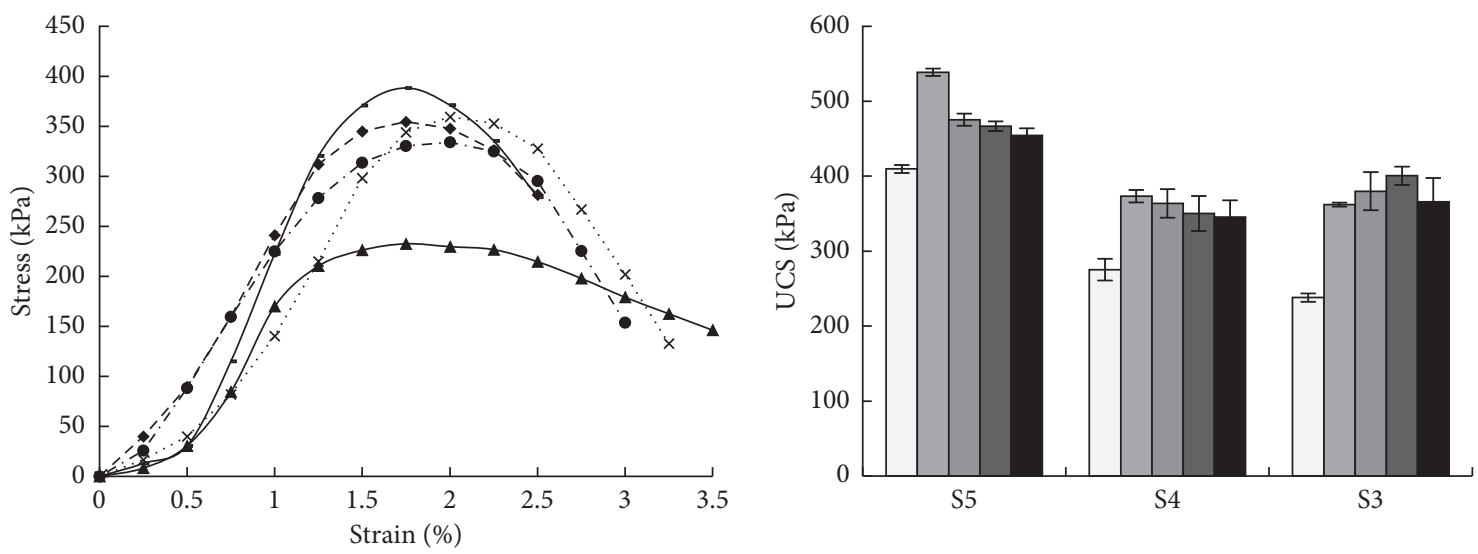

Freeze-thaw cycles

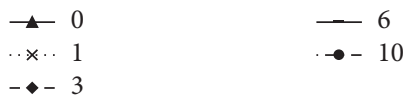

Freeze-thaw cycles

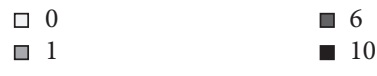

(d)

FIgURE 5: The stress-stain curves for samples (a) S5; (b) S4; (c) S3; and (d) UCS under freeze-thaw cycles. 


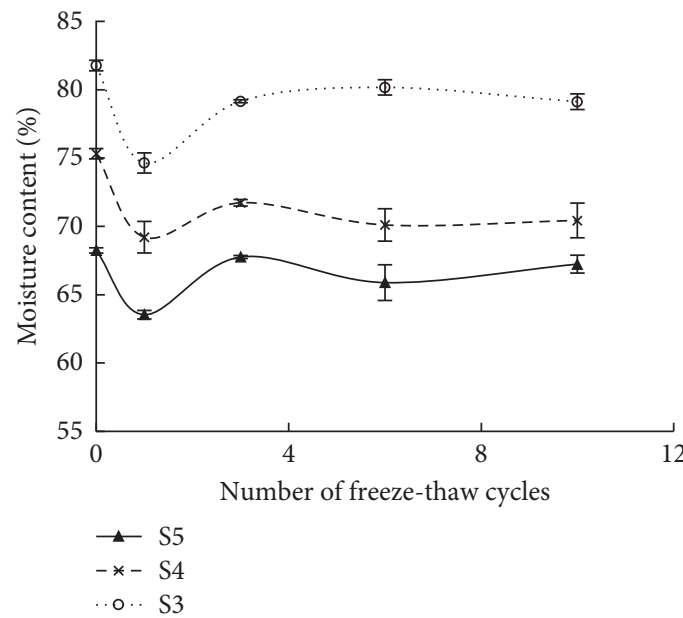

FIgURE 6: Variations in moisture content with freeze-thaw cycles.

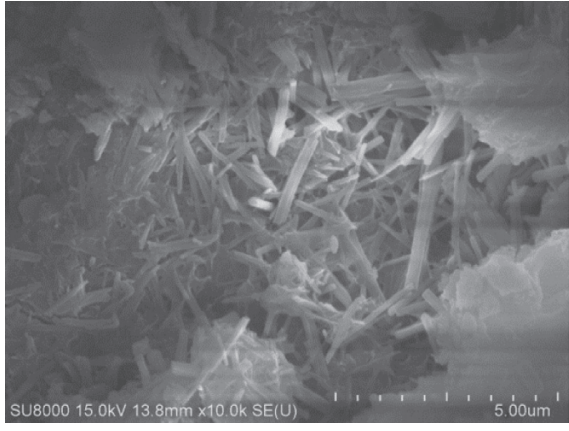

(a)

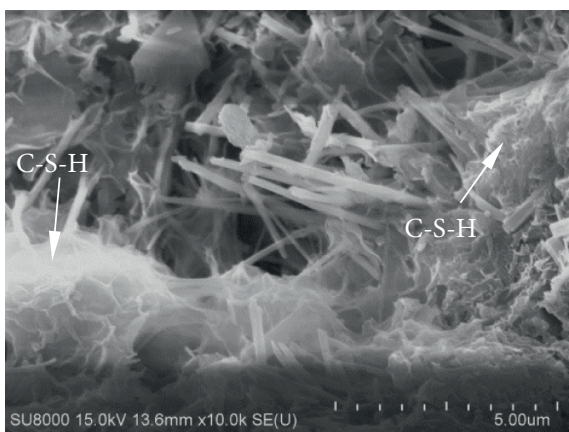

(c)

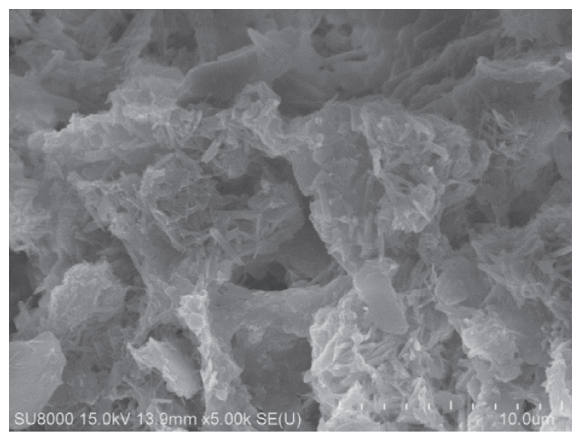

(e)

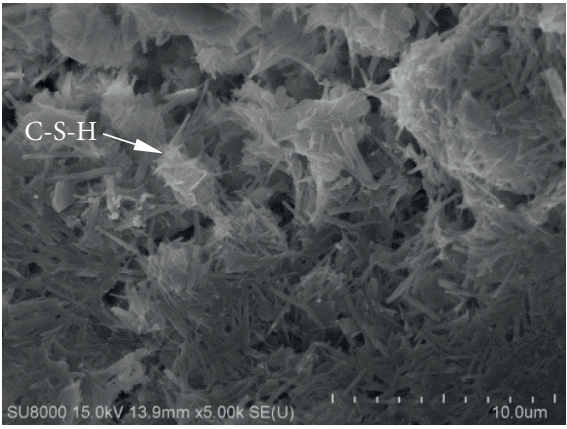

(b)

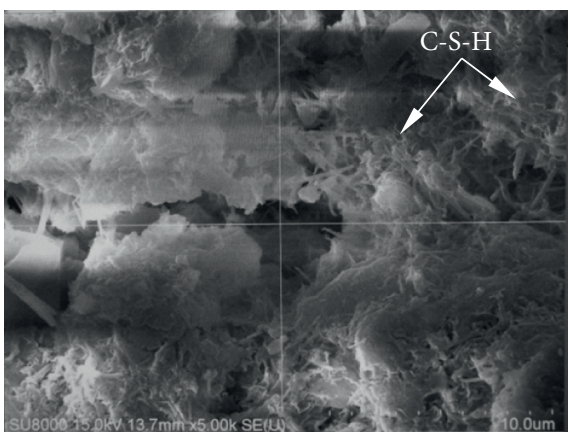

(d)

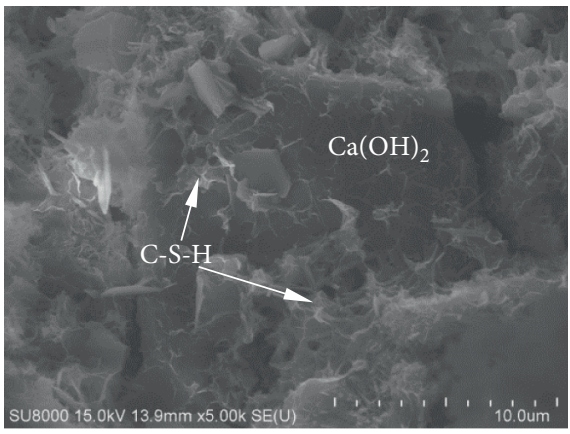

(f)

Figure 7: Continued. 


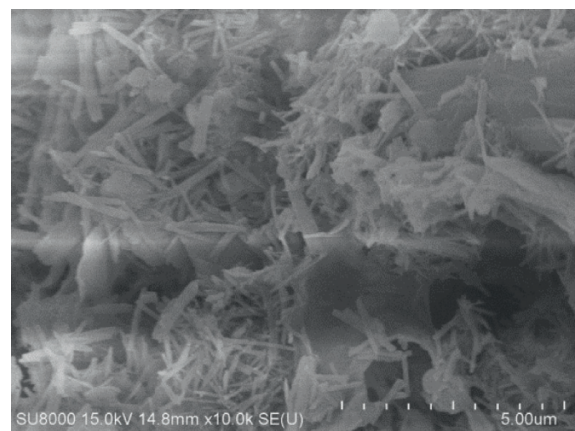

(g)

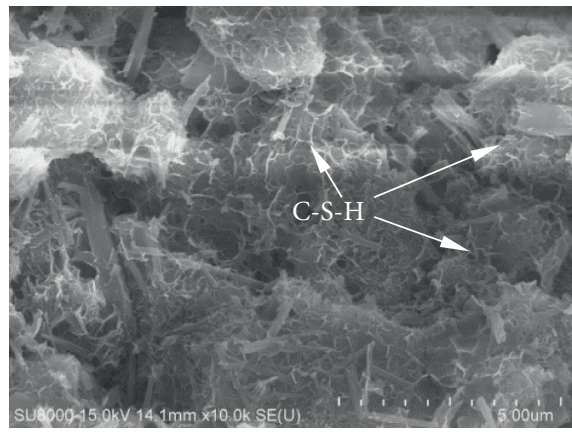

(i)

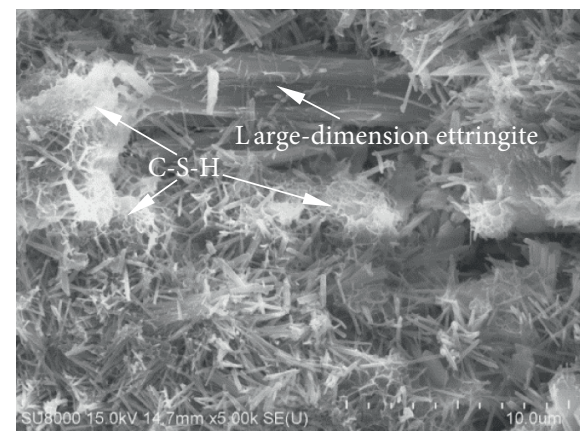

(h)

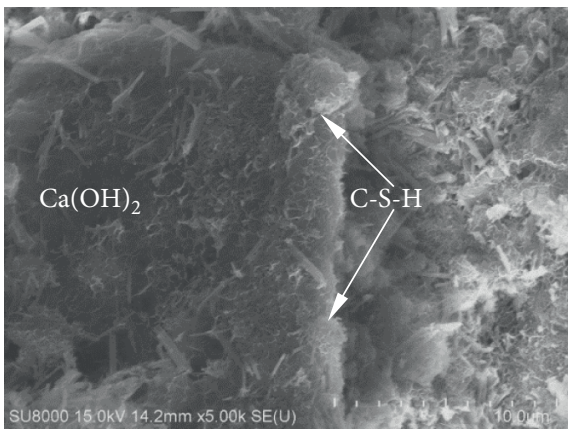

(j)

FiguRE 7: SEM images for sample S5 ((a), (b)) before cycle; ((c), (d)) after 3 dry-wet cycles; ((e), (f)) after 6 dry-wet cycles; ((g), (h)) after 1 freeze-thaw cycle; and ((i), (j)) after 6 freeze-thaw cycles.

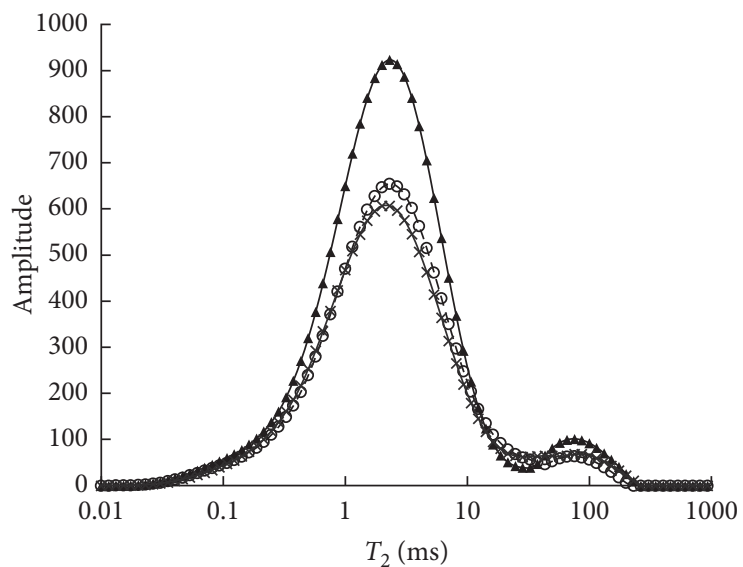

Drying-wetting cycles

-0
$-\theta-3$
$\rightarrow-6$

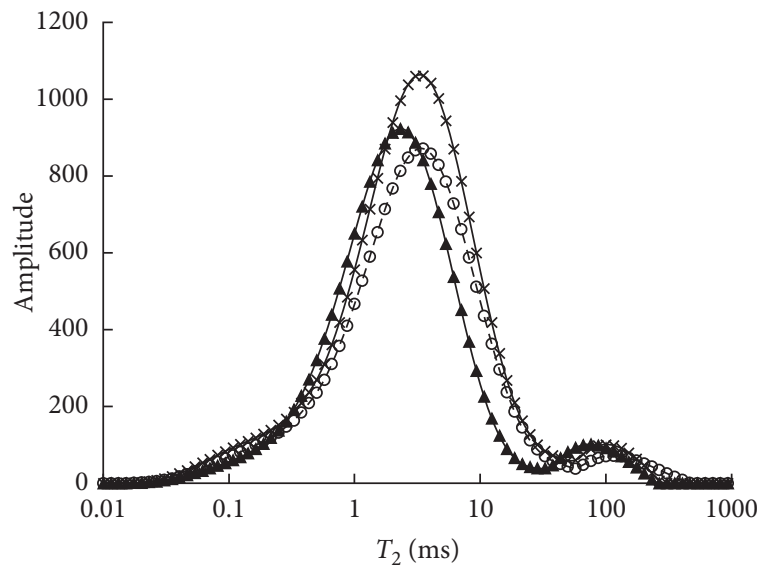

Freeze-thaw cycles

$\overrightarrow{-} 0$

$\rightarrow-10$

(a)

(b)

FIgURE 8: Effect of (a) dry-wet cycle and (b) freeze-thaw cycle on the T2 distribution curves of solidified sludge.

QL as solidifiers of sludge showed a good performance on stabilizing pollutants under dry-wet or freeze-thaw cycle environment.

The $T_{2}$ distributions from NMR analysis for the solidified sludge subjected to dry-wet and freeze-thaw cycles are shown in Figure 8 . The $T_{2}$ distribution showed a bimodal distribution. With the increase in dry-wet cycles, the values of $T_{2}$ at the peak amplitude did not vary, but the peak values of amplitude decreased, indicating the decrease in pore volume. This improved the UCS and dry-wet durability of the sample. Different from the distribution after dry-wet cycles, the $T_{2}$ distribution after the 1st freeze-thaw cycle 
moved right. The increase in the value of $T_{2}$ at the peak amplitude indicated that the pore size increased after the 1st freeze-thaw cycle. This might be attributed to the frost swell and the formation of large-dimension ettringite as shown in Figure 7(h). However, the decrease in the amplitude of the $T_{2}$ peaks helped to increase the UCS, along with the increase in the amount of C-S-H gels (Figure 7(h)). When the freezethaw cycles increased to ten, the peak amplitude increased, indicating the destructive effect on microstructure from the repeated freeze-thaw and a decrease in UCS.

Although the sludge, solidifier, and testing method used in this study were different from the references, the results of SR-GGBS-QL solidified sludge under dry-wet and freezethaw cycles were similar to those reported by Li et al. [8], Hu [12], Wang et al. [22], and Liu et al. [23]. Dehydrated shrinkage and water absorption swelling in dry-wet cycles, or frost swelling and thaw softening in freeze-thaw cycles, might weaken the microstructure [8]. If the adverse effects were less than the cementation effect from hydration reaction (especially the formation of C-S-H), the solidified sludge showed good durability. The factors such as phosphorus originated from sludge, chlorine and sulfur originated from SR [18], activation of GGBS by QL [26], and skeleton effect of SR particles [12] all played important roles in SR-GGBS-QL solidified sludge against dry-wet and freeze-thaw cycles. It should be noted that the dry-wet cycles and freeze-thaw cycles are no more than 10 in this study. The effect of further cycles should be investigated, which will be addressed in the future studies. The results in this study demonstrated that the SR-GGBS-QL solidified sludge had a good mechanical performance when used as a fill material under dry-wet and freeze-thaw environment.

\section{Conclusions}

A series of strength and microstructure tests were carried out on the SR-GGBS-QL solidified sludge subjected to dry-wet or freeze-thaw cycles. The main conclusions are as follows:

(1) The stress versus strain of the solidified sludge cured for 28 days showed a brittle failure characteristic, with the failure strain less than $2 \%$, regardless of the SR content, dry-wet cycle, or freeze-thaw cycle.

(2) With the increase in dry-wet cycles, the UCS of the solidified sludge increased first and then decreased after the 5th or 6th cycle, except for a slight decrease after the 1st cycle. The sharp increase in mass lost rate and the increase in moist content contributed to the UCS decrease for the 1st cycle. The frequent fluctuations in moist content during the dry-wet cycles might do harm to the microstructure of the solidified sludge. However, the hydration reaction continued, especially more ettringite and C-S-H formed during the dry-wet cycles, which contributed to a lower pore volume, compact microstructure, and a higher UCS than those before the cycles.

(3) After the 1st freeze-thaw cycle, the UCS of the solidified sludge increased markedly owing to the transformation of hydrocalumite and the formation of more C-S-H. With the further increase in freezethaw cycles, the UCS of the solidified sludge decreased, whereas the values after ten cycles were higher than those before the cycles. The frost swell and large-dimension ettringite formation led to enlargement of the pores, but C-S-H gels and compact microstructure after ten freeze-thaw cycles helped to maintain a high UCS.

(4) Under the effects of dry-wet cycles and freeze-thaw cycles, the UCS values of the solidified sludge were greater than $400 \mathrm{kPa}$ (for sample S5) or close to $350 \mathrm{kPa}$ (for samples S4 and S3), which met the strength requirement of filling materials. Moreover, pollutants, such as copper, arsenic, and chromium, were stabilized in the solidified sludge. Therefore, it is believed that SR-GGBS-QL solidified sludge has good dry-wet and freeze-thaw durability.

\section{Data Availability}

The data used to support the findings of this study are available from the corresponding author upon request.

\section{Conflicts of Interest}

The authors declare that they have no conflicts of interest regarding the publication of this paper.

\section{Acknowledgments}

Financial support for this research was obtained from the National Natural Science Foundation of China (Grant no. 41772332) and the Major Technology Innovation of Hubei Province (Grant no. 2017ACA090).

\section{References}

[1] L. Lang, N. Liu, and B. Chen, "Investigation on the strength, durability and swelling of cement- solidified dredged sludge admixed fly ash and nano-SiO ${ }_{2}$," European Journal of Environmental and Civil Engineering, pp. 1-21, 2020.

[2] R. Ke, H. X. Wang, Y. Z. Tan, and L. H. Wang, "Solidification of high organic matter content sludge by cement, lime and metakaolin," Periodica Polytechnica Civil Engineering, vol. 63, no. 1, pp. 53-62, 2019.

[3] Y. J. Chen, X. X. He, S. H. Zhang, X. Tan, and Y. Wan, "Strength and microstructure properties of solidified sewage sludge with two types of cement-based binders," Scientific Reports, vol. 10, no. 1, 2020.

[4] D. X. Wang, S. J. Di, X. Y. Gao, R. H. Wang, and Z. G. Chen, "Strength properties and associated mechanisms of magnesium oxychloride cement-solidified urban river sludge," Construction and Building Materials, vol. 250, Article ID 118933, 2020.

[5] W. Xiao, X. Yao, F. Y. Zhang, and A. Perrot, "Recycling of oily sludge as a roadbed material utilizing phosphogypsum-based cementitious materials," Advances in Civil Engineering, vol. 2019, Article ID 6280715, , 2019.

[6] F. Y. Liu, C. G. Zhu, K. J. Yang, J. F. Ni, J. Hai, and S. H. Gao, "Effects of fly ash and slag content on the solidification of 
river-dredged sludge," Marine Georesources and Geotechnology, vol. 39, no. 1, 2019.

[7] P. Chen, B. Feng, Y. J. Lin, and C. Lin, "Solidification and stabilization of sewage sludge and MSWI bottom ash for beneficial use as construction materials," Journal of Materials in Civil Engineering, vol. 31, no. 1, 2019.

[8] L. Li, W. Zhu, C. Lin, and T. Ohki, "Study of wet and dry properties of solidified sludge," Rock and Soil Mechanics, vol. 30, no. 10, pp. 3001-3004, 2009.

[9] C. Lin, W. Zhu, and J. Han, "Strength and leachability of solidified sewage sludge with different additives," Journal of Materials in Civil Engineering, vol. 25, no. 11, pp. 1594-1601, 2013.

[10] Y. L. Li, Study on landfill and durability of sewage sludge solidified with skeleton builders, $\mathrm{PhD}$ Dissertation, Huazhong University of Science and Technology, Wuhan, China, 2013.

[11] Q. Xue and Y. J. Chen, "Experimental study on municipal sludge dewatering capacity by using quicklime and slag," Desalination and Water Treatment, vol. 54, no. 6, pp. 1499-1506, 2015.

[12] X. T. Hu, Experimental study on physical and mechanical characteristics of solidified municipal sludge under complicated environment, PhD Dissertation, Liaoning Technical University, Fuxin, China, 2016.

[13] A. W. Yang, S. K. Yang, G. F. Xu, and W. Zhang, "Study of the long-term deformation characteristics of municipal sludge solidified soil under the coupling action of dry-wet cycles and initial static deviatoric stress," Advances in Civil Engineering, vol. 2020, Article ID 8824414, , 2020.

[14] S. Yan, J. Hou, and R. Liu, "Research on geotechnical properties and environmental effect of mixture of soda waste and fly ash," Rock and Soil Mechanics, vol. 27, pp. 2305-2308, 2006.

[15] J. Yang, Z. Liu, C. Yang, H. Li, Q. Lu, and X. Shi, "Mechanical and microstructural properties of alkali wastes as filling materials for abandoned salt caverns," Waste and Biomass Valorization, vol. 12, no. 3, pp. 1581-1590, 2021.

[16] J. Y. Sun and X. Gu, "Engineering properties of the new nonclinker incorporating soda residue solidified soil," Journal of Building Materials, vol. 17, no. 6, pp. 1031-1035, 2014.

[17] Z. X. Yang and J. G. Xie, "A new embankment filling technic applied on muddy soil by using alkali slug and waste cement concrete as modification," Highway Engineering, vol. 35, no. 1, pp. 72-75, 2010.

[18] J. He, X. K. Shi, Z. X. Li, L. Zhang, X. Y. Feng, and L. R. Zhou, "Strength properties of dredged soil at high water content treated with soda residue, carbide slag, and ground granulated blast furnace slag," Construction and Building Materials, vol. 242, pp. 118-126, 2020.

[19] G. Zhen, X. Lu, X. Cheng, H. Chen, X. Yan, and Y. Zhao, "Hydration process of the aluminate 12CaO-7Al2O3-assisted Portland cement-based solidification/stabilization of sewage sludge," Construction and Building Materials, vol. 30, pp. 675-681, 2012.

[20] B. Dohnálková, R. Drochytka, and J. Hodul, "New possibilities of neutralisation sludge solidification technology," Journal of Cleaner Production, vol. 204, pp. 1097-1107, 2018.

[21] J. G. Liu, X. W. Li, and T. He, "Application status and prospect of backfill mining in Chinese coal mines," Journal of China Coal Society, vol. 45, no. 1, pp. 141-150, 2020.

[22] D. Wang, J. Xiao, F. He, and Y. Zhou, "Durability evolution and associated micro-mechanisms of carbonated reactive MgO-fly ash solidified sludge from East Lake, China," Construction and Building Materials, vol. 208, pp. 1-12, 2019.
[23] W. H. Liu, J. W. Shu, X. L. Sun, Y. Hua, and F. F. Li, "Shear strength variations of solidified sludge during drying-wetting cycles," Journal of Civil and Environmental Engineering, vol. 41, no. 4, pp. 10-18, 2019.

[24] Q. Wang, Y. T. Yin, J. Y. Cui, and R. Tang, "Research of the strength model of cement solidified lead-contaminated soil under freezing and thawing cycles," Journal of Glaciology and Geocryology, vol. 39, no. 3, pp. 623-628, 2017.

[25] X. Hou, W. Ma, G. Y. Li, Z. W. Zhou, and Y. T. Huang, "Effects of freezing-thawing cycles on mechanical properties of loess solidified by sodium silicate," Journal of Glaciology and Geocryology, vol. 40, no. 1, pp. 86-93, 2018.

[26] Y. Yi, L. Gu, S. Liu, and A. J. Puppala, "Carbide slag-activated ground granulated blastfurnace slag for soft clay stabilization," Canadian Geotechnical Journal, vol. 52, no. 5, pp. 656-663, 2015.

[27] The Professional Standards Compilation Group of Japan, Method of Wetting and Drying Test for Water Absorption of Rocks, Method for Soil Testing, Japan Highway Society Handbook, Japan, 2001.

[28] T. Kamei, A. Ahmed, and T. Shibi, "The use of recycled bassanite and coal ash to enhance the strength of very soft clay in dry and wet environmental conditions," Construction and Building Materials, vol. 38, no. 1, pp. 224-235, 2013.

[29] The Professional Standards Compilation Group of American, Standard Test Methods for Freezing and Thawing Compacted Soil-Cement Mixtures, American Society for Testing and Materials, West Conshohocken, PA, USA, 2003.

[30] The Professional Standards Compilation Group of People's Republic of China, Standard for Geotechnical Testing Method, China Planning Press, Beijing, China, 2019.

[31] J. Xu, Y. Li, C. Ren, and W. Lan, "Damage of saline intact loess after dry-wet and its interpretation based on SEM and NMR," Soils and Foundations, vol. 60, no. 4, pp. 911-928, 2020.

[32] C. L. Zhang, W. Zhu, L. Li, G. J. Fang, and T. Ohki, "Field test of dike construction with solidified lake dredged material," China Harbour Engineeing, vol. 147, no. 1, pp. 27-29, 2007.

[33] US Environmental Protection Agency, Stabilisation/Solidifcation of CERCLA and RCRA Wastes, Physical Tests, Chemical Testing Procedures, Technology Screening, and Field Activities, U.S. Environmental Protection Agency, Cincinnati, OH, USA, EPA/625/6-89/022, 1989.

[34] M. Chrysochoou and D. Dermatas, "Evaluation of ettringite and hydrocalumite formation for heavy metal immobilization: literature review and experimental study," Journal of Hazardous Materials, vol. 136, no. 1, pp. 20-33, 2006.

[35] M. Secco, G. I. Lampronti, M.-C. Schlegel, L. Maritan, and F. Zorzi, "Degradation processes of reinforced concretes by combined sulfate-phosphate attack," Cement and Concrete Research, vol. 68, pp. 49-63, 2015. 